\title{
Underground mining at Ekati and Diavik diamond mines
}

\author{
J Jakubec SRK Consulting (Canada) Inc., Canada \\ D Lagacé SRK Consulting (Canada) Inc., Canada \\ B Boggis Dominion Diamond Mines ULC, Canada \\ LM Clark Rio Tinto, Canada \\ PA Lewis Rio Tinto, Canada
}

\begin{abstract}
Primary diamond deposits have been mined on an industrial scale only within the past 150 years, mainly as open pit mines. Although underground mining followed soon after open pits reached technical and/or economic limits, it only gained significant recognition in the past 20 years with the exception of Kimberley Mines. A relatively large number of underground mining methods were tested, implemented, and evolved mainly in South African mines. In the mid-1990s, Alrosa also started the development of the first underground diamond mine in Russia, Internationalnaya. Since then, underground mining has been implemented in several of their mines including Aikhal, Mir, and Udachny. China had also experimented with underground mining at Nhangma 701 Diamond Mine at the end of the nineties, but the largest development of underground diamond mining was experienced in Canada. Today, out of some 50 active diamond mines mining kimberlite or lamproite, approximately 15 are underground and another 15 have underground plans or hold the potential.
\end{abstract}

Ekati Diamond Mine is the first diamond mine to be developed near Lac de Gras in the Northwest Territories of Canada. The Koala North pipe had been developed and mined as an open pit; then later as a mechanised open benching operation to test the underground mining method and to provide access to the lower parts of the Panda and Koala pipes. Both the Panda and Koala pipes were also developed and mined underground once the open pit operations were completed. Koala North, North America's first underground diamond mining operation, was formally opened in 2002. Three principal underground mining methods: open benching, sublevel caving and incline cave mining were implemented at the Ekati mine.

Diavik Diamond Mine started open pit production in 2003. By 2005, underground development had commenced with plans to mine the A154 and A418 pipes using backfill methods. As geotechnical knowledge was gained, the mining methods were re-evaluated and the sublevel retreat (SLR) method was chosen for the A154S and A418 pipes, and blasthole stoping (BHS) with cemented rockfill (CRF) was chosen for the A154N pipe. In 2012, the open pits reached their ultimate depths and Diavik became a fully underground operation. The current mine life is approximately 2025.

In 2008, De Beers started underground mining on kimberlite sill at Snap Lake. However, the mine closed in 2015 and it is currently on care and maintenance. The focus of this paper is to document experiences with underground mining of kimberlite pipes at the Ekati and Diavik mines.

Keywords: sublevel caving, sublevel retreat, incline caving, Ekati mine, Diavik mine, diamond mining, underground mining

\section{Introduction}

Primary diamond deposits have been mined on an industrial scale only within the past 150 years; initially as open pits, then shortly followed by underground mining as open pits reached technical or economical limits. Underground mining of diamond deposits was introduced in South Africa in the 1890s, and for a century, South Africa was the only country with underground diamond mines. The next country to 
implement underground diamond mining outside South Africa was Russia when Alrosa started the development of Internationalnaya. Since then, underground mining was implemented in several mines in Yakutia including Aikhal, Mir, and Udachny. China had also experimented with underground mining at Nhangma 701 Diamond Mine at the end of the 1990s.

The largest growth of diamond underground mining in recent years was experienced in Canada, specifically at Ekati, Diavik, and Snap Lake diamond mines, all of which are located in extremely challenging conditions in the Canadian Arctic.

Today, out of some 50 diamond mines worldwide exploiting primary deposits, mainly kimberlite pipes, approximately 15 are underground and another 15 or so have underground plans or the potential to mine underground.

\section{Canadian diamond mines overview}

To date, underground mining has been implemented on six kimberlite pipes and one kimberlite sill. These are Panda, Koala and Koala North at the Ekati mine, A418, A514N and A514S at the Diavik mine, and at Snap Lake. At least two other pipes are being developed for underground mining; Renard 3 in Quebec and Misery pipe at Ekati. The focus of this paper is to document experiences with underground mining of kimberlite pipes at the Ekati and Diavik mines. The location of Canadian diamond mines is shown in Figure 1.



Figure 1 The location of diamond mines in Canada

\subsection{Ekati Diamond Mine}

The Ekati Diamond Mine was the first diamond mine to be developed near Lac de Gras in the Northwest Territories of Canada. Mining commenced with an open pit operation first at Panda, followed by an open pit at Koala North, then Koala. Project feasibility analysis was then implemented to identify suitable methods for extracting underground resources beneath the Panda and Koala open pits. The Koala North pipe had been selected as a trial underground mine location for the purposes of testing Arctic, permafrost 
mining methods, and to provide access to the lower elevations of the Panda and Koala pipes. The upper $40 \mathrm{~m}$ of the Koala North pipe was mined in the early 2000s as an open pit which provided grade and geotechnical information, and a prepared surface for the transition to underground mining. An aerial view of the Ekati mine is shown in Figure 2.

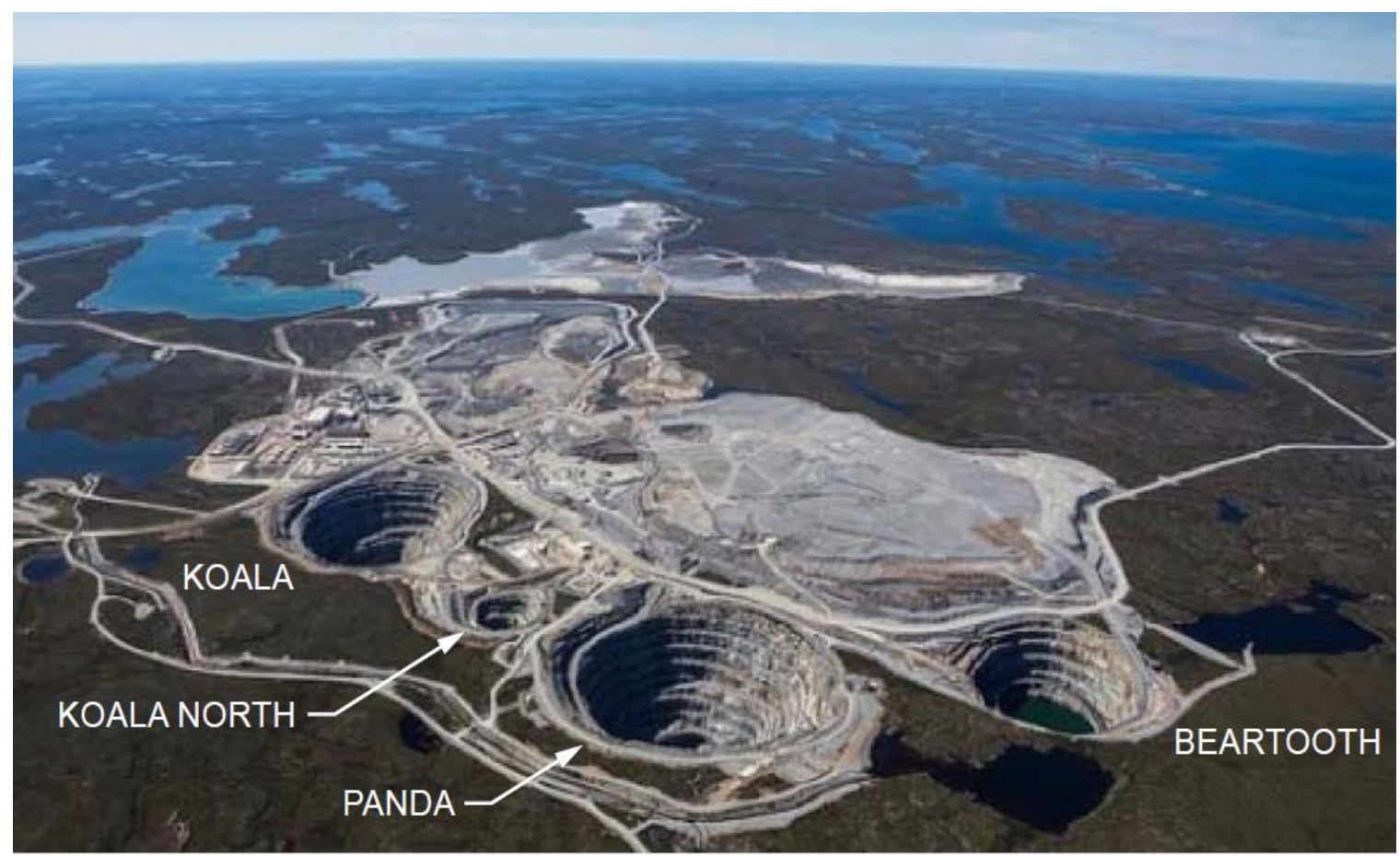

Figure 2 Aerial view of Ekati Diamond Mine

In 2002, Koala North underground was formally opened and became North America's first underground diamond operation. The Koala North pipe has been successfully mined as mechanised open benching down to $2115(-350 \mathrm{~m})$ Level and proved that sublevel retreat (SLR) is technically feasible, and an economically viable mining method for exploiting kimberlite pipes in the Arctic. Since then, the Panda and Koala pipes were also mined as underground mines after open pits were completed, and several other pipes are being investigated for underground mining. At the Ekati mine, three principal underground mining methods were utilised including SLR, sublevel caving (SLC) and incline cave (IC) mining. Table 1 illustrates the production to-date from the Ekati underground and open pit mines.

Table 1 Summary of Ekati production-to-date

\begin{tabular}{lllll}
\hline $\begin{array}{l}\text { Mining } \\
\text { method }\end{array}$ & Pipe & $\begin{array}{l}\text { Mining } \\
\text { method }\end{array}$ & $\begin{array}{l}\text { Production rate } \\
\text { (Mwmt/annum) }\end{array}$ & Tonnes produced (Mdmt) \\
\hline \multirow{4}{*}{ Open Pit } & Panda & Open pit & 2.8 & 14.2 \\
& Koala & Open pit & 3.5 & 10.6 \\
& Beartooth & Open pit & 0.4 & 1.8 \\
& Misery & Open pit & 1.4 & 8.7 (includes inferred satellites) \\
& Fox & Open pit & 3.1 & 24.3 \\
& Panda & SLR & 1.2 & 4.7 \\
Underground & Koala & SLC, IC & 1 & IC still operating \\
& Koala North & SLR & 0.3 & 1.8 \\
\hline
\end{tabular}




\subsection{Diavik Diamond Mine}

Diavik Diamond Mine started open pit production in 2003. By 2005, underground development had commenced with initial plans to mine the A154 and A418 pipes using backfill methods. As geotechnical knowledge was gained, the mining methods were re-evaluated and the SLR method was chosen for the A154S and A418 pipes. However, blasthole stoping (BHS) with cemented rockfill was chosen for the A154N pipe. An aerial view of Diavik Diamond Mine is shown in Figure 3.

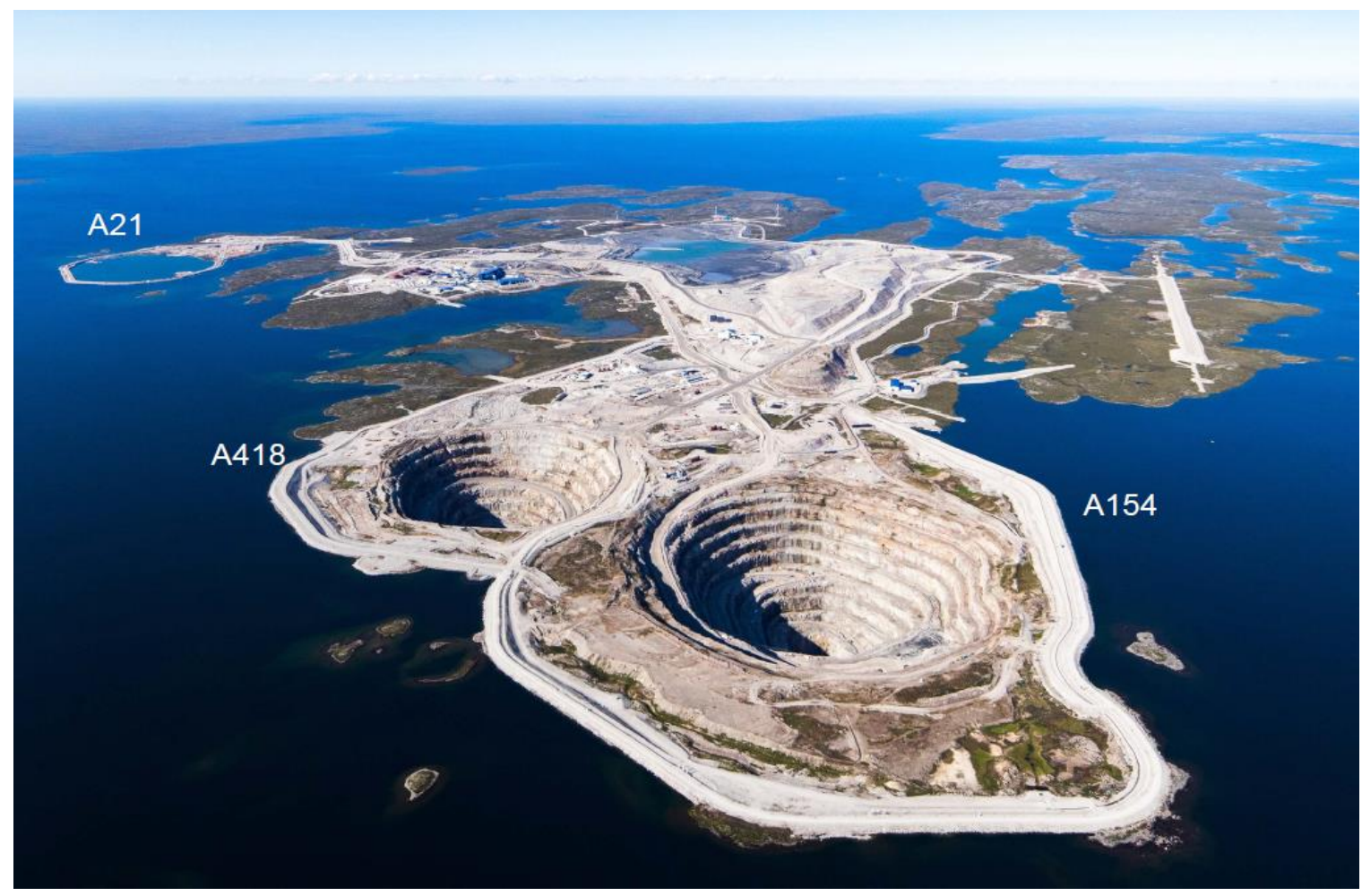

Figure 3 Aerial view of Diavik Diamond Mine

In 2012, the open pits reached their ultimate depths and Diavik became a fully underground operation. The current life-of-mine is planned to 2025. A mining summary to-date is illustrated in Table 2.

Table 2 Summary of Diavik production to-date

\begin{tabular}{|c|c|c|c|c|}
\hline Mining method & Pipe & $\begin{array}{l}\text { Mining } \\
\text { method }\end{array}$ & $\begin{array}{l}\text { Production rate } \\
\text { (Mt/annum) }\end{array}$ & $\begin{array}{l}\text { Tonnes } \\
\text { produced }\end{array}$ \\
\hline Open pit (2003-2010) & $\begin{array}{l}\text { A154S and } \\
\text { A154N }\end{array}$ & Open pit & 1.61 (avg.) & 12.9 \\
\hline Open pit (2008-2012) & A418 & Open pit & 1.10 (avg.) & 5.5 \\
\hline Underground (2010 start) & A154N & $\mathrm{BHS}$ & $\begin{array}{l}0.57 \text { (avg.), } \\
0.75 \text { (current) }\end{array}$ & 4 \\
\hline Underground (2010 start) & $\begin{array}{l}\text { A154S and } \\
\text { A154N }\end{array}$ & SLR & $\begin{array}{l}0.40 \text { (avg.), } \\
0.49 \text { (current) }\end{array}$ & 2.8 \\
\hline Underground (2011 start) & A418 & SLR & $\begin{array}{l}0.58 \text { (avg.), } \\
1.10 \text { (current) }\end{array}$ & 3.5 \\
\hline
\end{tabular}




\subsection{Underground mining methods}

Most of the underground mining methods can be grouped into three basic categories:

- Caving methods.

- Open stope methods (unsupported).

- Supported methods.

Diamond mining worldwide throughout history developed and implemented numerous underground mining techniques; the combinations included 19 different mining methods and variants from all three groups mentioned above.

Several options were considered for underground mining at both mines. With the exception of the A154N pipe, mass mining methods including open benching, sublevel retreat, SLC and incline caving were selected.

The BHS method with cemented rockfill used at Diavik is not considered a mass mining method; therefore, it is not described in this paper. The SLR method was recently introduced to Canada; hence, this paper will focus on the SLR mining method and commentary will also be provided on incline cave.

\subsubsection{Sublevel retreat mining}

The decision to select the SLR method was made as a result of technical, economical and safety risk considerations. Competent country rocks, favourable geometry, relatively competent kimberlite, and the Arctic context of the projects played an important role in the mining method selection process at both the Ekati and Diavik mines. The schematic section illustrating the SLR method is shown in Figure 4.

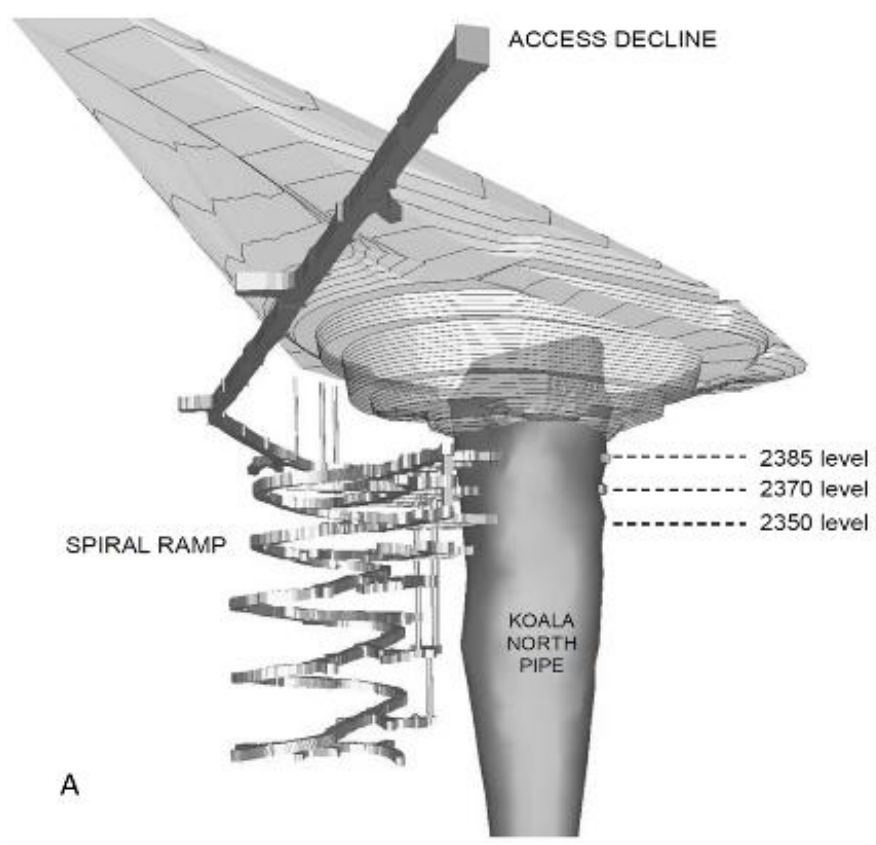

Figure 4 (a) Isometric view of Koala North underground mine; (b) SLR stopes; and, (c) Schematic section through an SLR mine
B

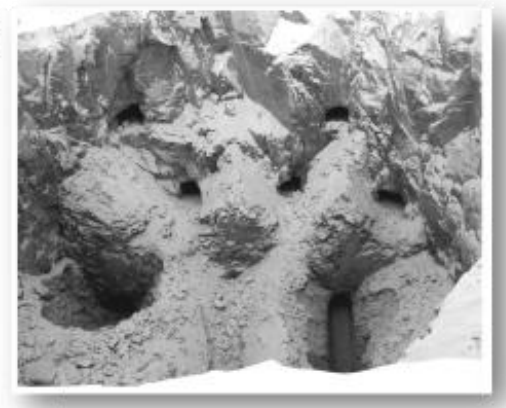

C

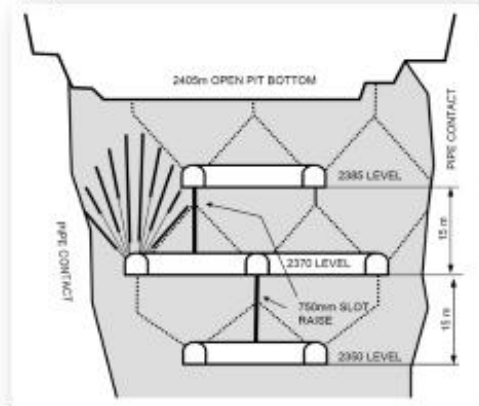


The SLR method was developed and first implemented by De Beers in 1948 at Premier Mine and evolved into a better design at Finsch (Figure 5) and Koffiefontein mines as transitions between open pits and underground mines. A more detailed description of the open benching and compound ring design and performance was published by Guest (1989), Silverton and Smart (1992) and Guest (1996), and was summarised by Jakubec et al. (2017).

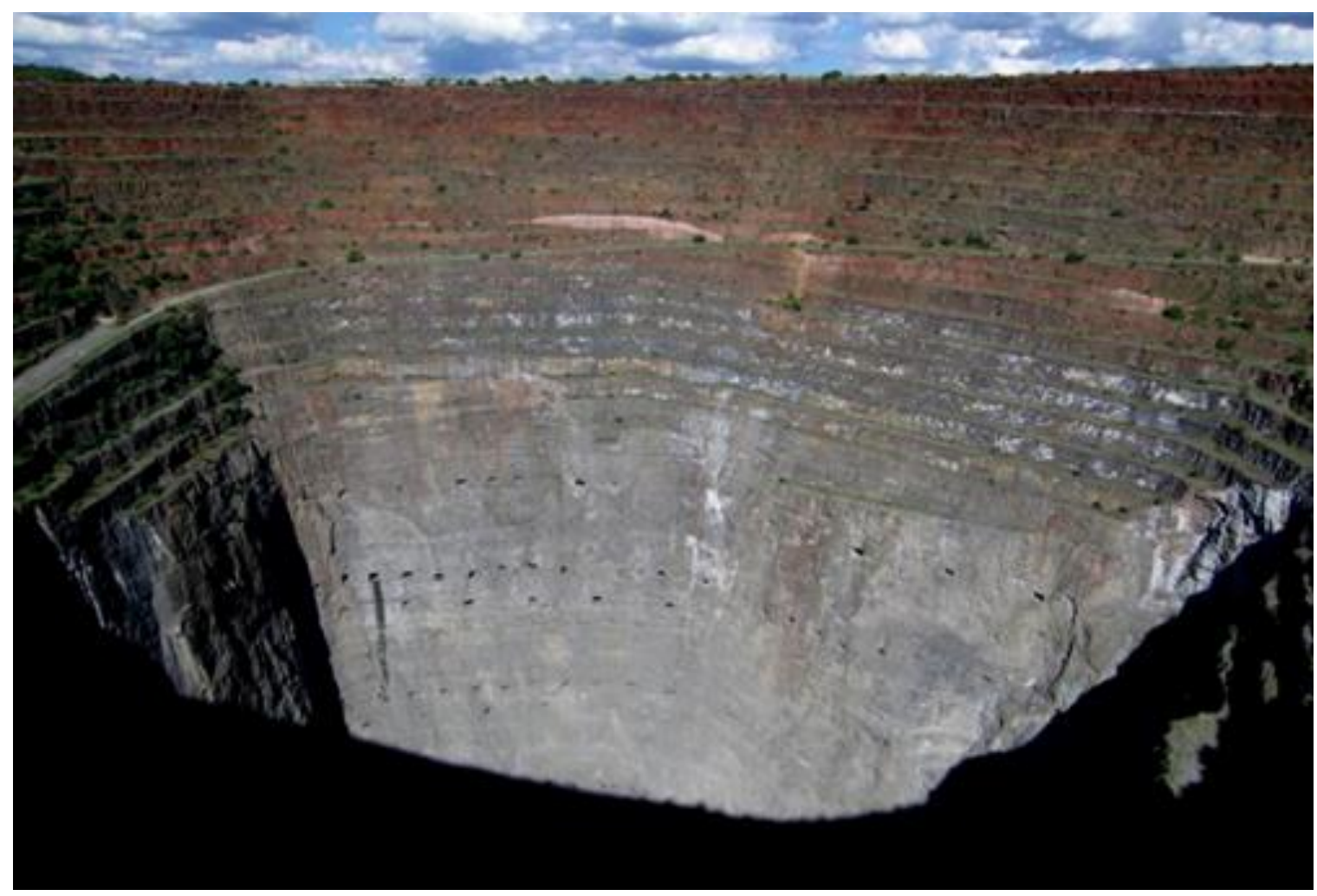

Figure 5 Aerial view of Finsch Mine - Note tunnels developed for open benching method

In 1999, open benching design was introduced to the Ekati mine by Chris Page and Jarek Jakubec. The initial design included sublevels at $15 \mathrm{~m}$ horizontal spacing and crosscuts at $15 \mathrm{~m}$. The sublevel spacing was subsequently increased to $20 \mathrm{~m}$, and after successful trials, the method was implemented at Panda pipe. After completion of several levels, open benching was converted to sublevel retreat; a variation of open benching with protective cover of broken muck pile left on the extraction levels to increase safety.

SLR mining at Panda was successfully completed in 2010 (Figure 6). SLR at the Ekati mine is described in Jakubec and Long (2004).

The SLR method was also introduced at Diavik A154S and A418 pipes (Figure 7). 


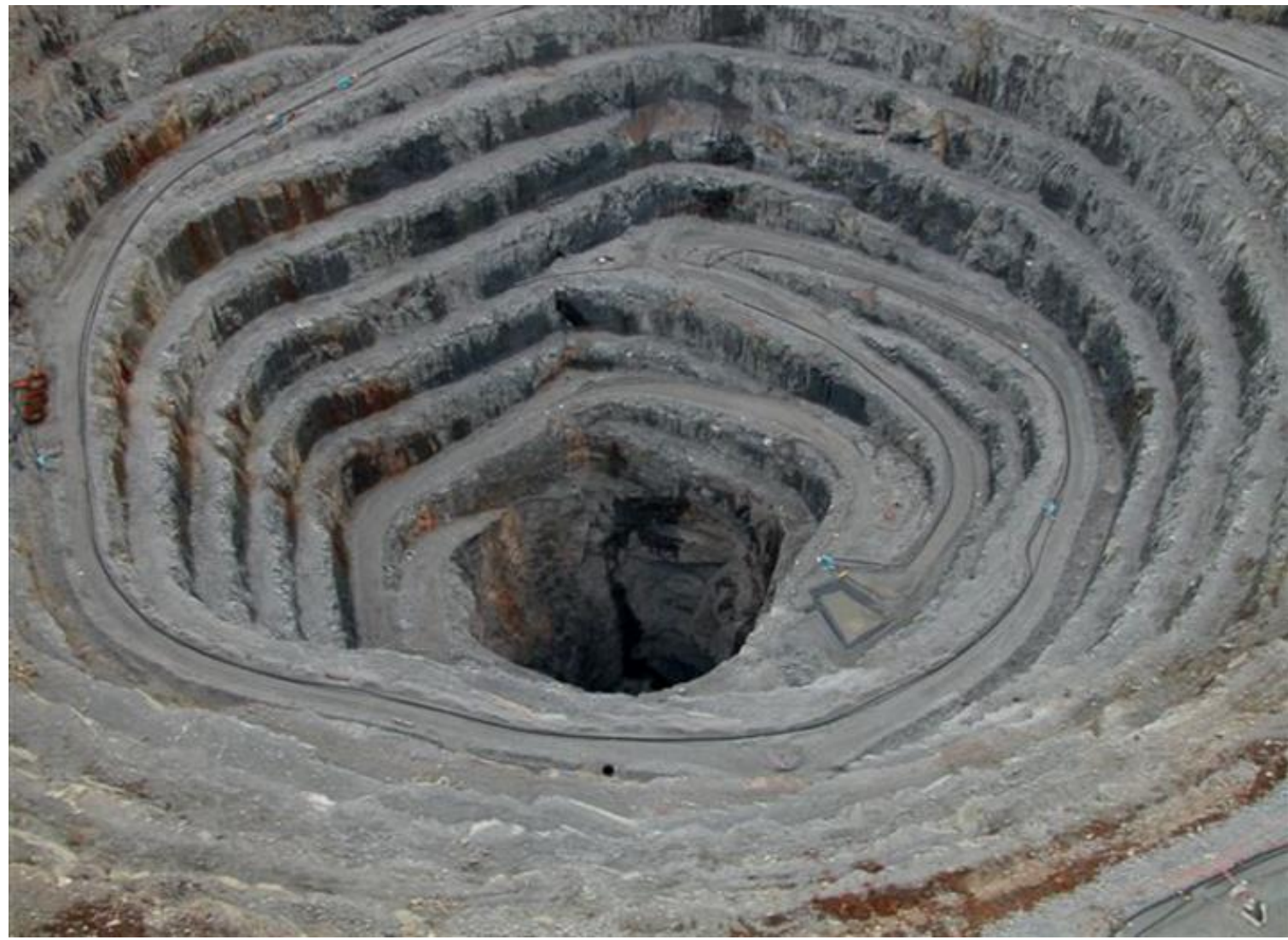

Figure 6 Empty SLR stope at the bottom of the Panda open pit

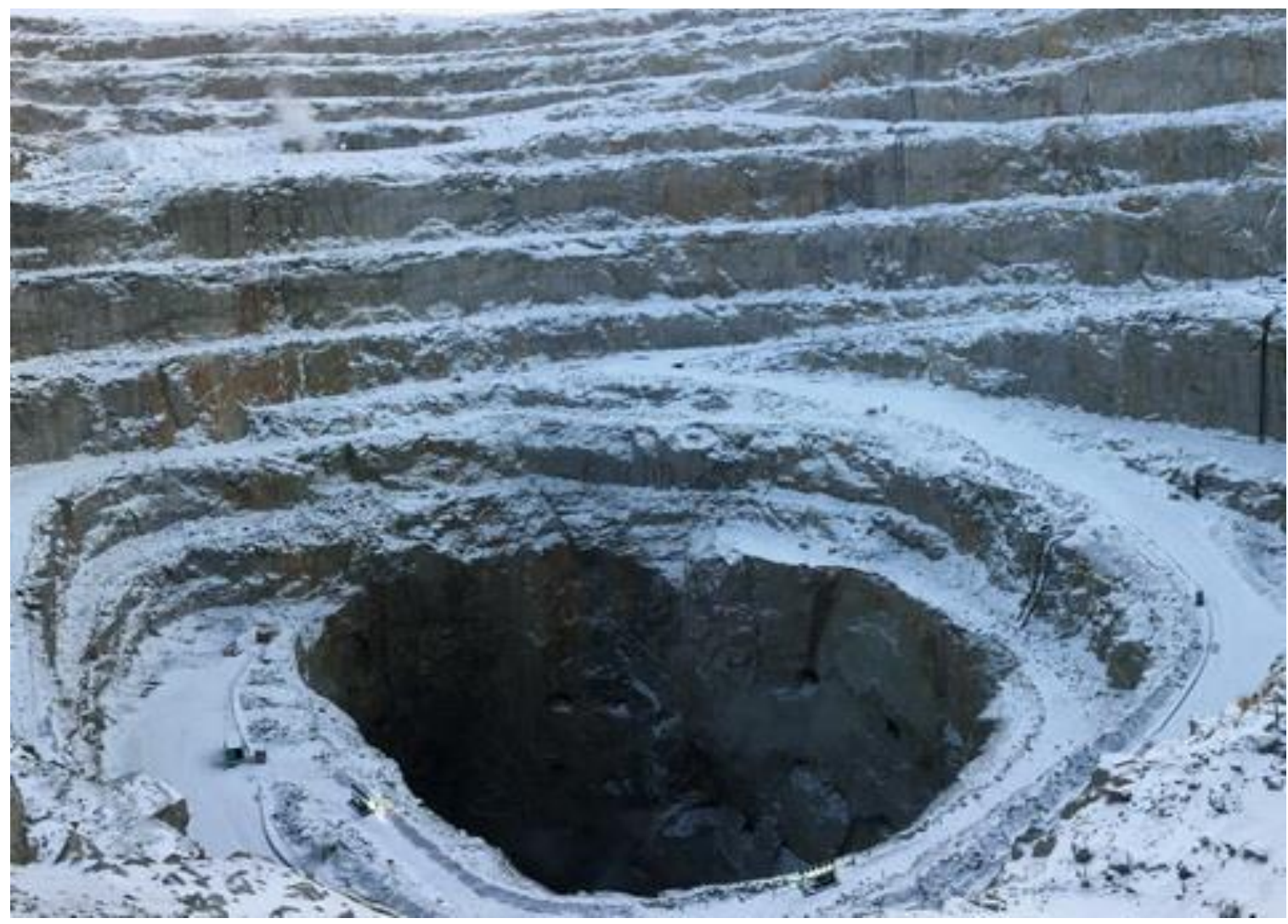

Figure 7 Empty SLR stope at the bottom of the A154 open pit 
To date, the SLR method has been successfully implemented at both the Ekati and Diavik diamond mines on four pipes. Some of the operational experiences are described in the next section.

\section{$2.4 \quad$ Sublevel caving}

Sublevel caving is one of the mass mining methods that has been implemented over the past 100 years. It was first used in diamond mines in South Africa. As pipes were getting narrower and caveability of the kimberlite became problematic, the SLC method was established at Kimberley Mines in 1979. The most recent SLC has been successfully completed at the Koala kimberlite pipe at the Ekati mine. In Africa, Gem Diamonds developed Ghaghoo Diamond Mine as SLC but it was put into care and maintenance in 2017. SLC is also being developed below Block 4 at Finsch Mine.

At the Ekati mine, SLC mining was implemented at Koala pipe some $150 \mathrm{~m}$ below the pit floor, beneath the low-grade kimberlite (phase five) that was not economically feasible to mine by underground mining methods such as SLR. Sublevels were developed at $20 \mathrm{~m}$ vertical intervals and parallel crosscut tunnels were developed at $15 \mathrm{~m}$ spacing across the pipe. Slots were established at the end of the crosscuts and individual rings were blasted in each crosscut (Figure 8).
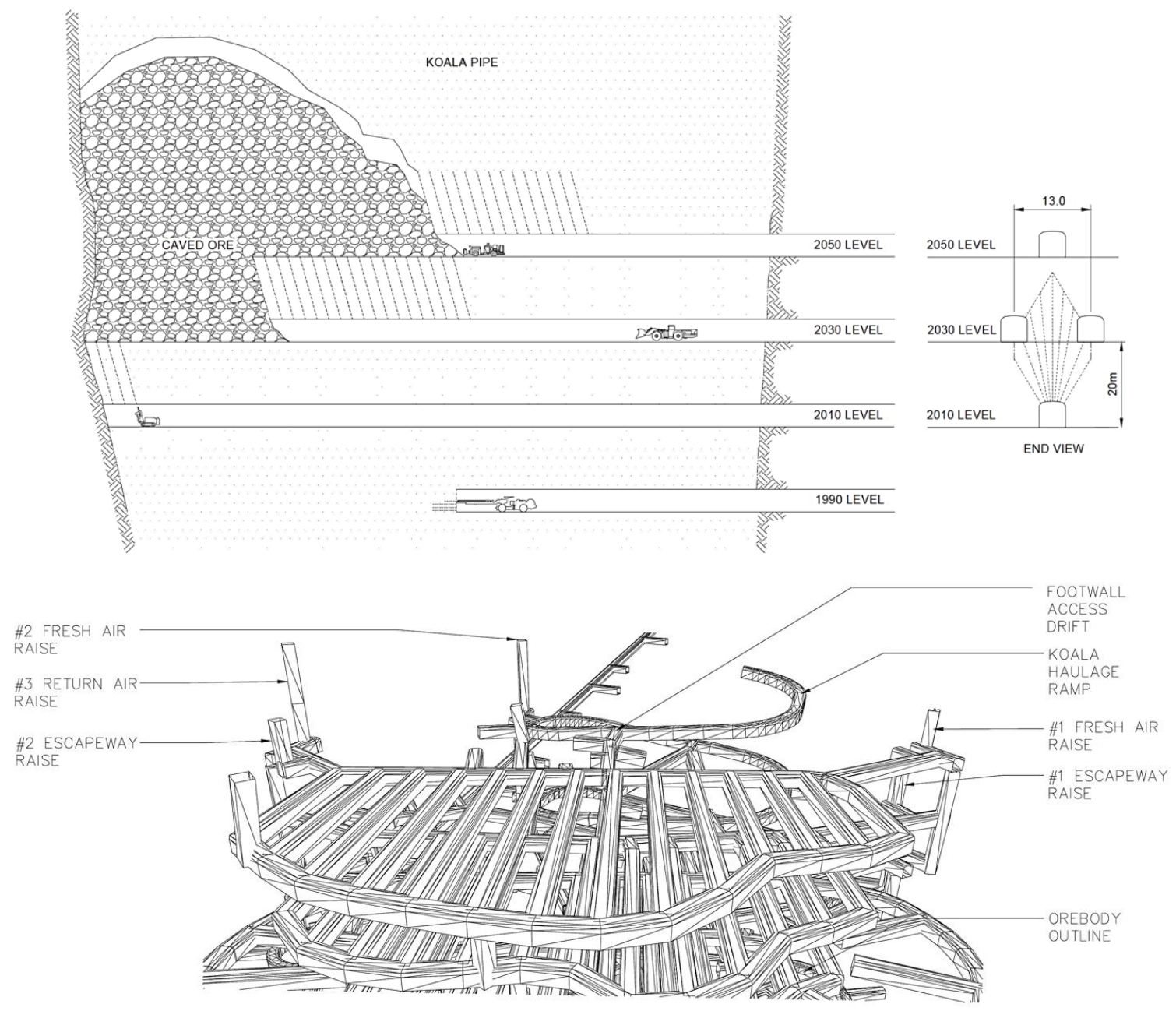

Figure 8 Schematic section and 3D view of Koala Mine

Several levels with staggered crosscuts were operated at the same time. The following extraction rates were used as guidelines.

- 2050 Level: $40 \%$ draw (allows cave to start).

- 2030 Level: $80 \%$ draw. 
- 2010-1930 Level: 100\% draw.

- 1910-1870 Level: 120\% draw.

- 1850-1830 Level: final drawdown of the '60 m dilution bin' and caved crown pillar.

An additional 'ring pull' draw level around the circumference of the pipe at the 1970 Level has been added to draw in phase five ore earlier and at the crusher level.

The ore-handling system for Koala consists of an ore dump at 1970 Level with a grizzly and rock breaker, and includes horizontal ore storage located nearby. The MMD 1000 Twin Roll Primary Ore Sizer and conveyor system is used to transport the ore out of the mine.

As the pipe was getting narrower and irregular with mud rushes becoming an increasing challenge, it was decided to extract a low-grade pillar with the remaining SLC resource by the incline cave method at the bottom of the SLC.

\subsection{Incline caving}

An incline cave has a mining configuration where rows of drawpoints are offset vertically and follow an incline plane. In the incline plane, the individual drawpoints (drawbells) in the row and between individual sublevels are spaced so that they allow full interaction, more or less the same way as in the horizontal layout. In the incline layout, this interactive draw is fundamentally different from SLC where there is no or limited interaction between individual drawpoints, although the layout of sublevels appears to be similar.

Incline caving was studied to pre-feasibility level at Finsch for Block 5 (Paucar \& Mthombeni 2004) but it was not implemented there. The first incline cave in a diamond mine was implemented in 2014 at the Ekati mine for the Koala pipe. The design included two levels of double-sided and one level of single-side incline cave with 47 drawpoints at approximately $15 \mathrm{~m}$ spacing following the pipe geometry. Incline caving performed well and enabled extraction of residual SLC and low-grade phase five material that would otherwise be uneconomical for the SLC method. Figure 9 illustrates the cross-section through Koala pipe.

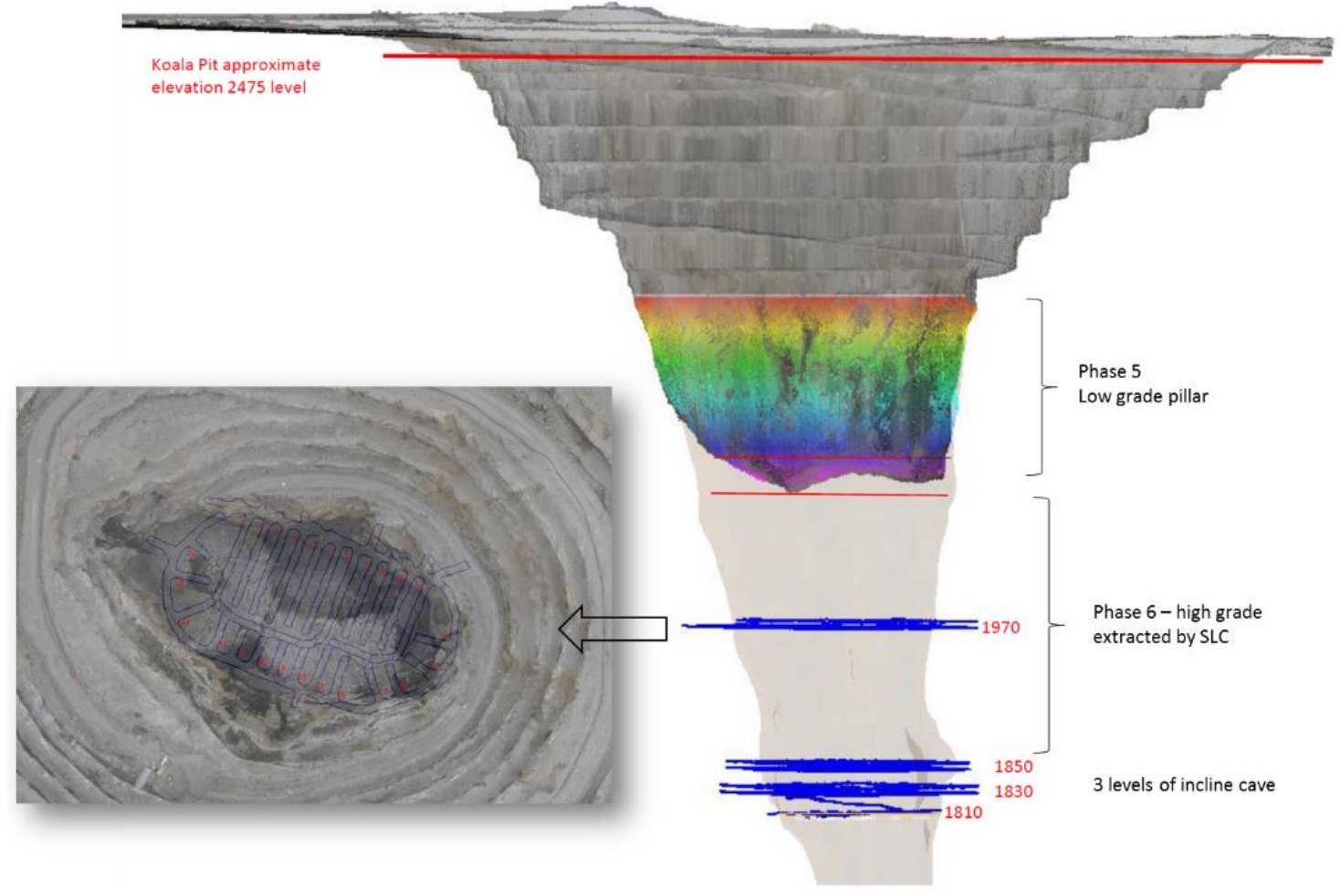

Figure 9 Schematic section of Koala pipe illustrating location of different mining methods with 1970 Level plans projected to the actual crater 


\section{Operational challenges in an Arctic context}

Operating an SLR underground mine in winter poses a number of significant challenges, specifically freezing muck piles, the stability of the country rock contacts, development in permafrost, ventilation, application of shotcrete and production drilling.

\section{1 $\quad$ Freezing muck piles}

During the winter months, the broken muck pile in the stope after the production blast will freeze if not removed. The level of freezing depends on water content. This can potentially result in operational problems if measures to mitigate the impact are not implemented. The key to the successful ore recovery is removal of freshly blasted muck pile as soon as possible and prevention of water access to the stope. Historically, hang-ups of frozen muck have been encountered and treated with additional caution. These are treated with additional caution as the combination of rock and ice makes it even less predictable than a rock hang-up. Any muck left behind primarily on the apexes between the drawpoints was recovered on the next level below when it was blasted. Although sometimes experienced, the truck 'carry back' of the ore due to freezing has never been a serious problem. Frozen kimberlite has been found to flow very differently to wet kimberlite. Frozen kimberlite tends to flow out of the SLR drawpoints in larger, more angular pieces. The muck piles generally have a steeper angle of repose and mix less with the broken waste above as it is drawn down. Conversely, in summer the kimberlite crumbles more easily, resulting in a much finer particle distribution. If water is added to the warm, fine kimberlite, the angle of repose could become very shallow; it has the potential to liquefy and flow out the drawpoint. During the initial levels when using SLR, the recovery from each blast was much lower in the winter than in the summer. Winter storms can also accumulate excess snow in the muck pile (Figure 10).

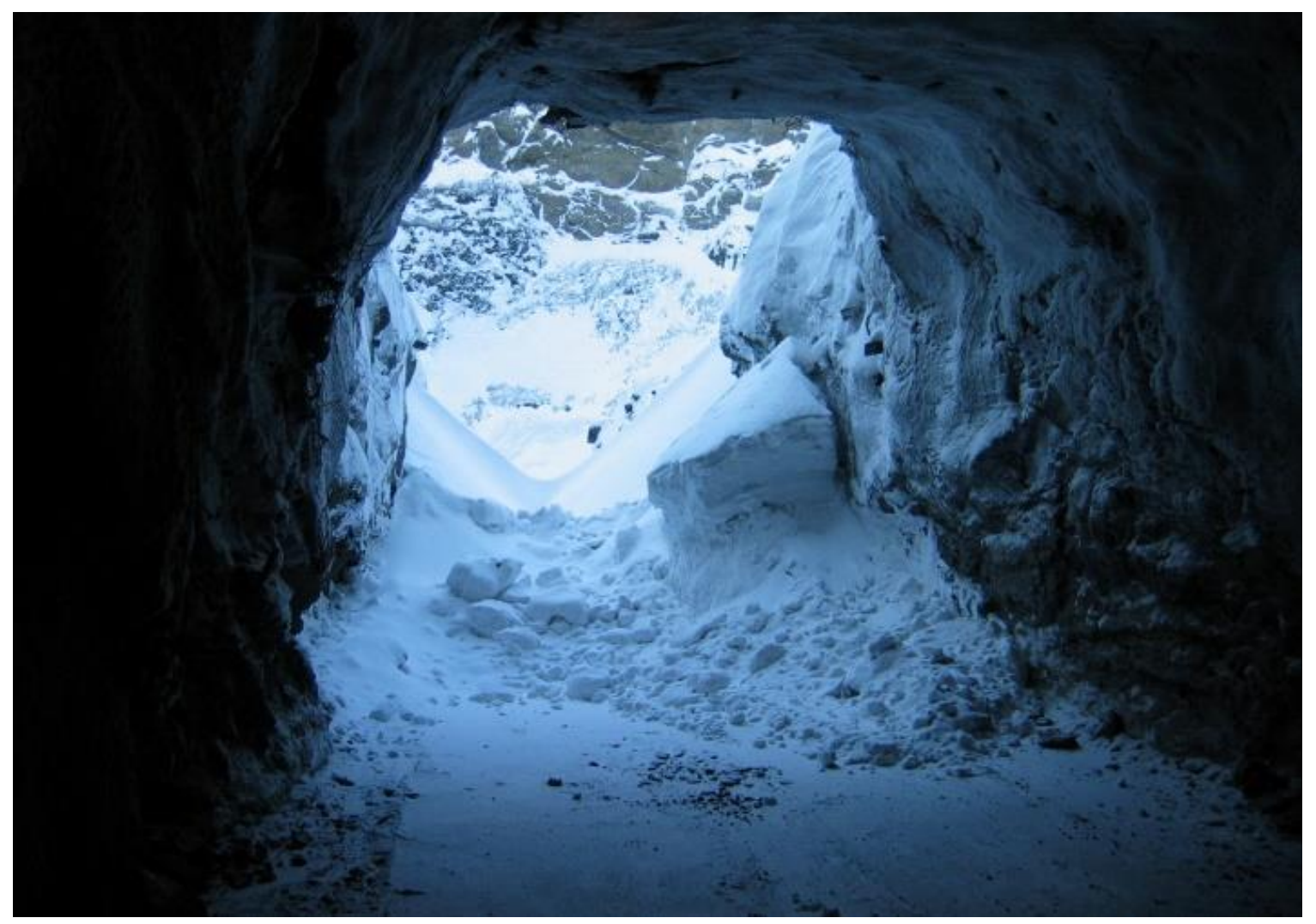

Figure 10 Snow accumulation in the drawpoint at Koala North 


\subsection{Wallrock stability}

At the Ekati mine, the open pit walls and walls of the SLR stope are completely frozen from October to May with no stability problems encountered. In late May, with the walls warming up due to the longer exposure to sun and warmer temperatures followed by freezing during the short nights, small-scale rockfalls were experienced. This is mainly due to the 'ice jacking' effect on open joints. The north wall thaw back was up to $7 \mathrm{~m}$ and south walls was up to $3 \mathrm{~m}$.

At Diavik, the same trend is seen. The large majority of SLR contact wall stability issues occur between May and October. Contact wall failures are variable in size. Large failures have been in excess of 100,000 $t$ (Figure 11). This wallrock granite is then reporting to drawpoint as dilution, often as oversize (Figure 12). To manage safety at the SLR drawpoints, the drawpoints are left choked. Regular drone surveys are used to characterise the levels of broken muck over the drawpoints. Draw control procedures are also utilised to help maintain an appropriate level of broken muck over the drawpoints. Monitoring of the contact walls is done through a combination of surface and underground systems. The surface utilises in-pit radar (Figure 13) and prism monitoring in addition to a suite of other instruments. The underground uses a range of extensometers, crackmeters and time-domain reflectometers. All instruments are tied into a real-time monitoring network. Trigger action response plans have been developed to evacuate the SLR levels if contact wall instability is detected.

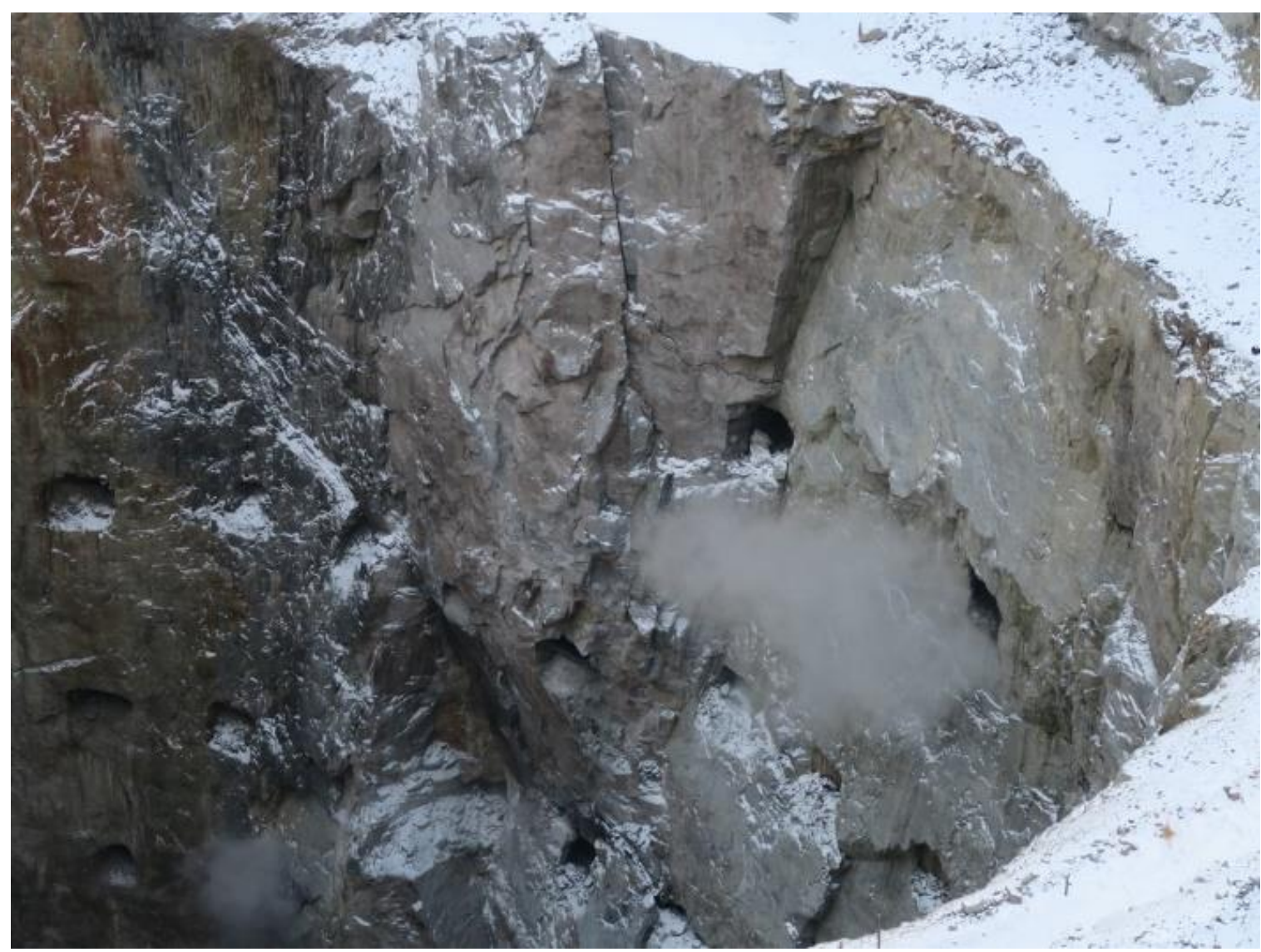

Figure 11 Wallrock failure at the A418 pipe at Diavik Diamond Mine 


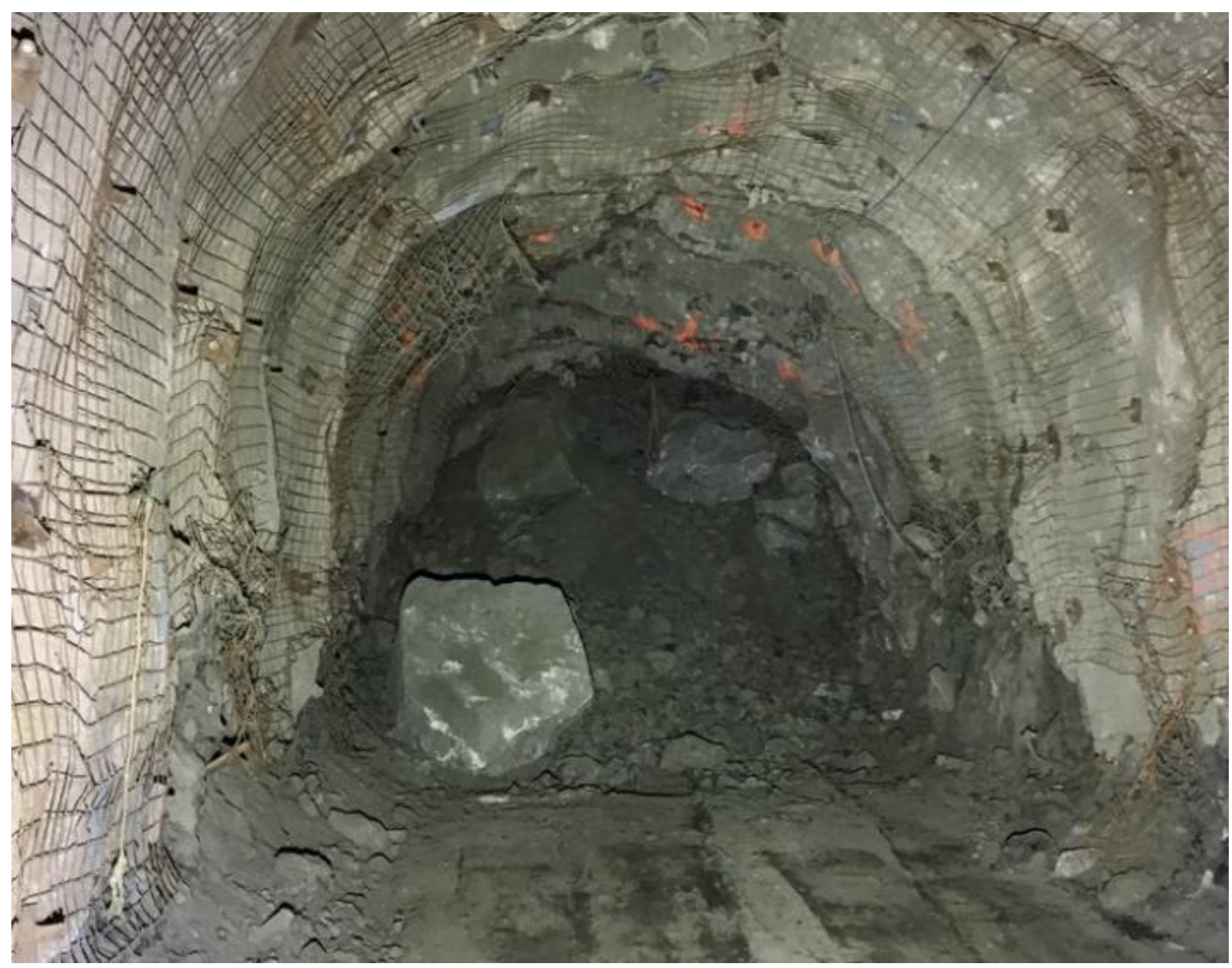

Figure 12 Granite wallrock oversize dilution in the A418 drawpoint

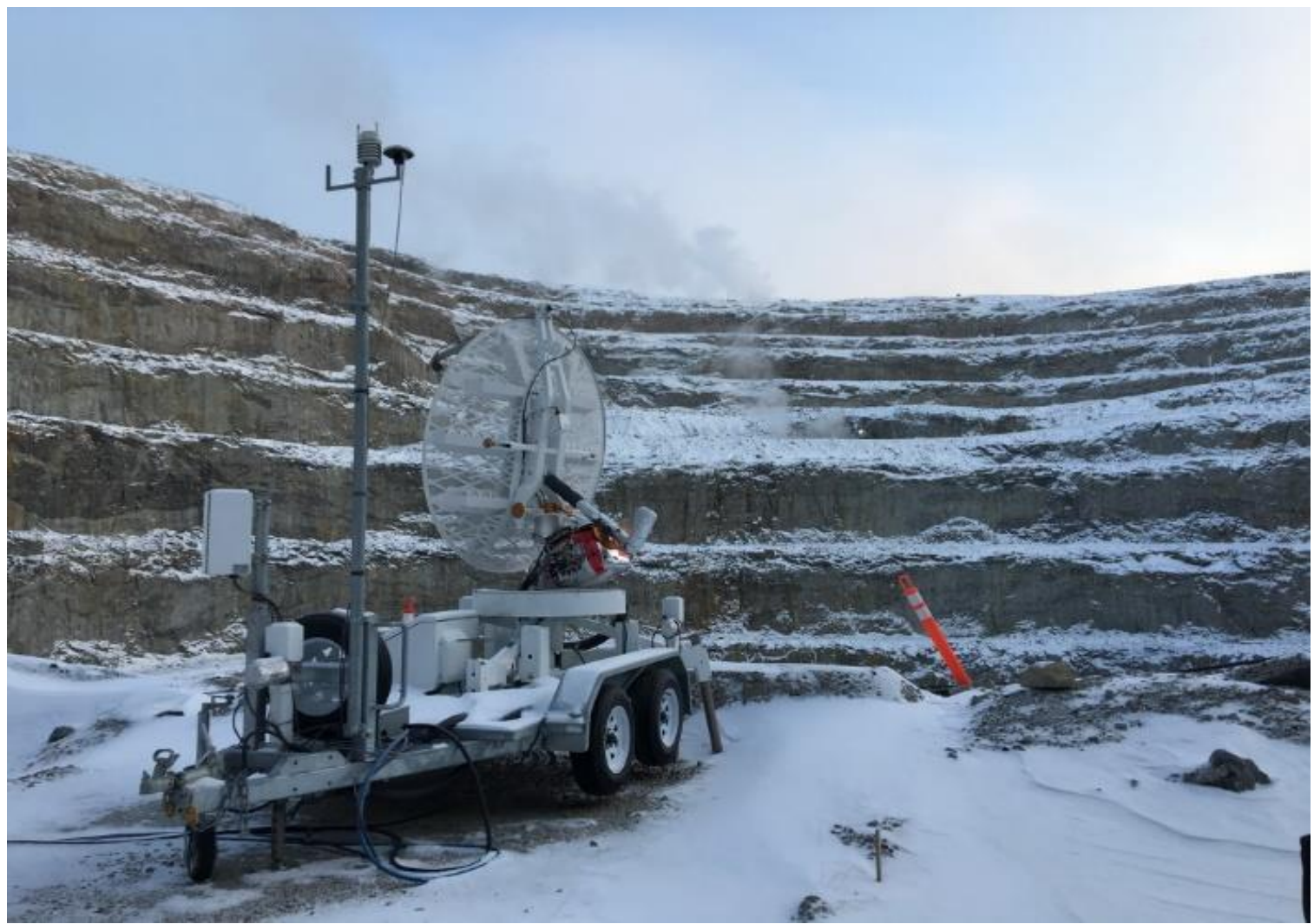

Figure 13 Radar monitoring system at Diavik Diamond Mine 
The teleremote capability of scoop trams on SLR levels has proven invaluable regarding maintaining production during geotechnical events, and is necessary to manage other geotechnical risks such as mud rushes.

\subsection{Trafficability and ice build-up}

When the Panda ramp had advanced to the point that it was developed below the permafrost (300 $\mathrm{m}$ below surface), water began to seep through the joints in the rock mass. Ice began to build up on the haulage road and it quickly became a problem with equipment moving on the ramp. After evaluating the alternatives, the decision was made to install heaters on the fresh air intake raise; within a few days of commissioning the system the roads were free of ice. During the winter, there is also ice build-up on the escape ladder way, and cleaning procedures were developed to combat the problem.

The Diavik orebodies were originally underwater and, consequently, Diavik had very little permafrost within the underground workings. Within the confines of the water retention dyke, many geotechnical structures allow melted and rain water to flow into the underground from surface areas as the former lake bed had no permafrost. During the winter, the cold temperatures cause these structures to freeze and seal, reducing the amount of water and the paths available for water to reach underground. Because of this pattern, the underground roadways are very dry in the winter, and wet and at times slick in the summer.

\subsection{Fogging - cold and heated air}

After the heaters were installed on the Panda fresh air intake raise, a pocket of fog would develop where the unheated air from Koala North mixed with the heated air. A 'fog zone' was created between the 2245 Level and 2205 Level of the Koala North ramp. The fog would begin to dissipate once temperatures rose above $-30^{\circ} \mathrm{C}$. Procedures were developed that allowed traffic to move safely through this zone and prohibited pedestrians.

The lack of permafrost and the inflow of seepage water forced Diavik to use mine air heaters from its beginning. Five primary intake fans with heaters create a net overall positive pressure ventilation system. The air exiting the portals creates similar fog zones. Block traffic lights with sensors and running lights have been installed to control and assist traffic entering and exiting the mine.

On the production SLR levels, two ventilation set-ups are utilised. In the A418 pipe, a forced fresh air raise at the back of the level pushes air across the level and onto the ramp. In the A154S pipe, a return air raise draws air from the ramp across the level and into the raise. This results in the A418 levels having positive pressure and the A154S levels having negative pressure relative to the outside atmosphere. The exhaust raise on the A154S levels was dictated by the ventilation requirements of the blasthole stoping orebody nearby.

When drawpoints are cracked open in the A418, the air exhausts to the pit, where in the A154S outside cold air is drawn underground. When this occurs, the individual drawpoint is overcome with fog to the point of nearly no visibility, ice begins to form on the sill and service water pipes freeze and crack. When this occurs, it is nearly impossible to carry out any work in the heading to rectify the situation. For this reason, ventilation doors are installed at the entrance of each A154S level with secondary fans mounted in the door frame. This increases the relative pressure on the level, ensuring air is exhausted out cracked drawpoints. While this setup has the same end result as the setup on the A418, it requires more infrastructure and management while restricting movement due to the doors.

\subsection{Impact of cold on productivity, men and equipment}

Temperatures in the Ekati underground workings follow the temperature outside with a significant delay of approximately one month. Long development headings were still $+4.50^{\circ} \mathrm{C}$ after three weeks of -10 to $-15^{\circ} \mathrm{C}$ outside. The main reason is due to heat generated by the working equipment at the headings as well as low airflow due to leakage in the vent ducting. Before the heaters were installed, some of the mine areas could 
become very cold in the winter months. The open drawpoints in the kimberlite could easily reach $-50^{\circ} \mathrm{C}$ with the wind chill factor.

Temperatures underground at Diavik always remain above $0^{\circ} \mathrm{C}$ due to the mine air heaters. Care must be taken, however, for crews when returning to surface due to the sudden drastic temperature change. Diesel for the mine air heaters represents a large portion of Diavik's underground operating budget. Optimisation of these heaters to as low a set point as possible using underground sensors and a programmable logic controller (PLC) has reduced heating costs substantially. Energy costs are exceedingly high in the Arctic due to the remote and isolated location of the mines. Primary ventilation automation is in the process of being implemented using louver regulators. A combination of the equipment on the level (tracked by RFID tag) and $\mathrm{CO}$ gas sensors using a PLC will alter louver positions, automatically redirecting primary flow. This reduces power cost for the primary fans, as well as reduced mine air heater requirements by only using the ventilation that is required. Power savings are further achieved by remote control of the underground secondary fans. All fans are automatically shut down for end-of-shift blasting and only what is required for gas clearing is restarted.

The Ekati underground crews work an 11-hour shift, but their effective time at the face is 8.5 hours. Based on the assessment of the performance of the underground crews in the winter months, the rotation of the underground personnel was changed from six weeks in and three weeks out to two weeks in and two weeks out. The main reason for this was the impact of the severely cold temperatures. It was felt that six weeks proved to be too long to be exposed to such a work environment. At Diavik, underground crews work 12-hour shifts on a two weeks in and two weeks out rotation.

The primary impact that the cold had on the equipment was on the hydraulic systems. This was especially true at the beginning of the project when ruptured hydraulic hoses were a common occurrence. This was because the equipment was more frequently exposed to the low temperatures on the surface outside the mine. Indirectly, there was also increased damage to the equipment due to the use of brine for drilling. This issue is discussed below separately. Light vehicles regularly travelling between the dry, cold surface and the wet, warm underground are also prone to regular part failures. While not a primary piece of mining equipment, the restricted ability to transport personnel due to low light vehicle availability in the winter had a direct effect on mine productivity.

\subsection{Shotcrete mix for cold climate}

At the Ekati mine, the current dry shotcrete mix used underground is comprised of $480 \mathrm{~kg}$ of ready mixed shotcrete (type 30 including silica fume), and 1,120 kg of aggregate water is added at the nozzle.

In order to achieve a good quality product, it is important to introduce the QA/QC program that covers the entire process from batching to application. Daily inspections by the geology/geotechnical staff are the best tool to inspect shotcrete performance.

The overall volume of shotcrete used per metre of kimberlite development is $1.4 \mathrm{~m}^{3}$. It was found during testing that the shotcrete set poorly at $-18^{\circ} \mathrm{C}$ and never attained full strength. However, from -5 to $20^{\circ} \mathrm{C}$, the compressive strength averaged $38 \mathrm{MPa}$, which was acceptable for Koala North application.

At Diavik, wet mix shotcrete is utilised. It is batched in a surface batch plant and delivered underground using Normet transmixers. It is applied using Normet spraymecs. Approximately $25 \mathrm{~m}^{3}$ of shotcrete is sprayed daily. The current mix design for a cubic meter is $585 \mathrm{~kg}$ Type 10 cement, 1,508 kg $10 \mathrm{~mm}$ minus aggregate, $215 \mathrm{~L}$ of water, plus admixtures. The aggregate is crushed onsite and kept warm in the winter months using steam. Batch consistency is maintained by monitoring the mixer power draw. Strength requirement is $5 \mathrm{MPa}$ in $8 \mathrm{hrs}$ and $35 \mathrm{MPa}$ in 28 days. 


\subsection{Development and production drilling}

Two issues have to be considered: development drilling in permafrost and production longhole drilling in the kimberlite. A Simba production drill is shown in Figure 14.

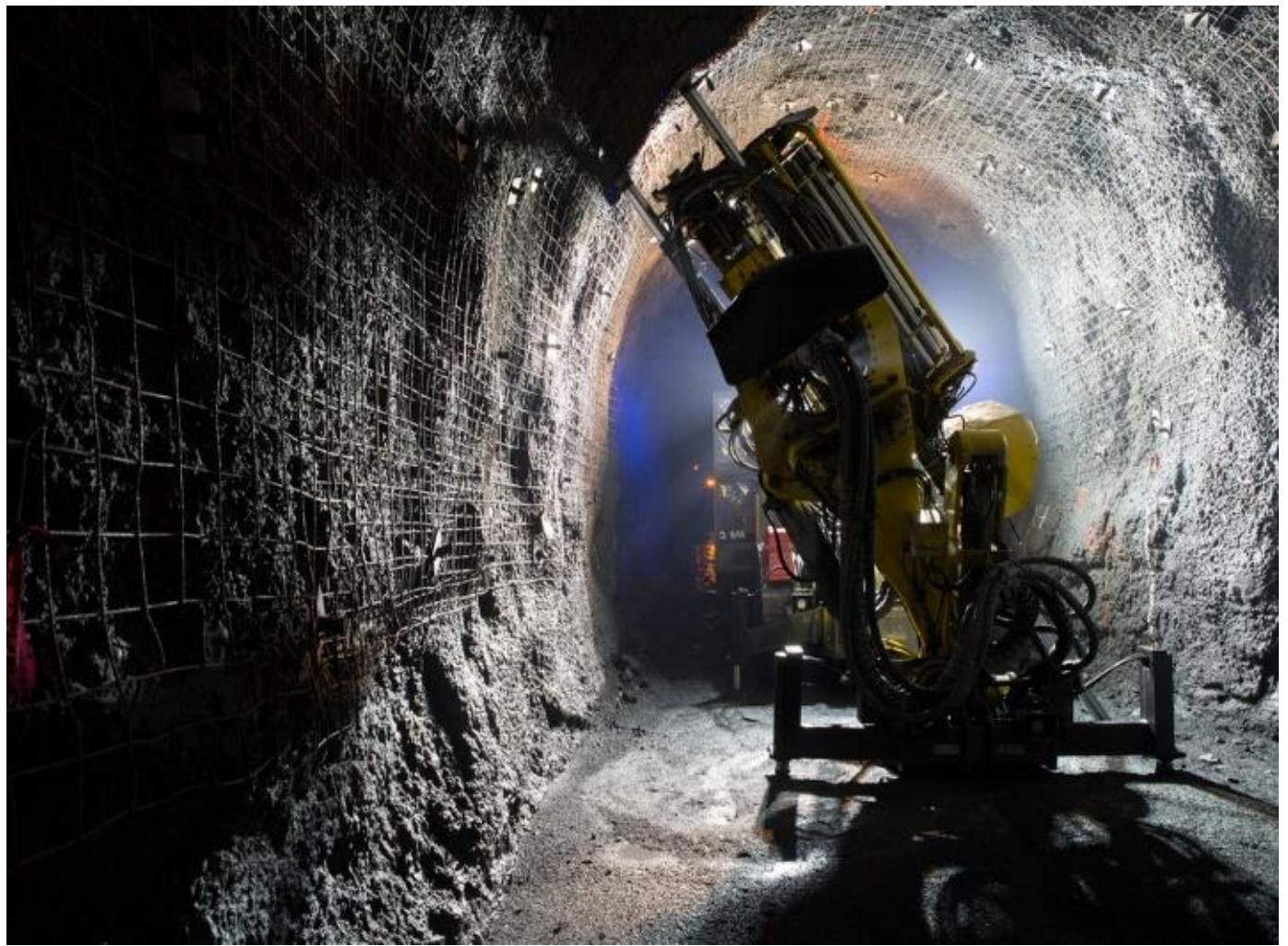

Figure 14 Underground production drilling at Diavik Diamond Mine

Due to the susceptibility of kimberlite to weathering, the production drillholes in permafrost at the Ekati mine were planned to be drilled dry. This proved to be initially successful and the only problem that had to be combated in the context of the cold climate is re-drill due to the icing up of the drillholes. Although this problem could have a significant impact, it is experienced only during the spring snow melt and freeze-up period, while in the remainder of the year, there were virtually no issues with re-drilling. Dust management issue were found to be a limiting factor and wet drilling was successfully introduced later at Panda and Koala where the kimberlite was below the permafrost.

The kimberlite at Diavik is also weak. However, production drilling is generally carried out using conventional water flushing with few issues. When muddy kimberlite is encountered, the air/water mist feature on the drill is used and successfully prevents hole washout. Due to the softness and poor quality of the kimberlite, bridging and hang-ups are regularly encountered. If drilling is required in the vicinity of drawpoints or when drilling through previously blasted ground, teleremote drilling is used to ensure the safety of the operators.

The development in the permafrost granite required drilling with brine. Some increased corrosion problems were experienced on underground equipment. It was also found that high-quality two-stage settling of solids out of re-circulated brine is essential.

At Diavik, development through weak kimberlite required the creation of a very cautious drill-and-blast method. All headings at Diavik developed in ore for SLR are developed in a horseshoe shape. The drift is near-round except for a flat floor. Further to the drift shape, depending on conditions of the specific heading, a combination of the following is used: 2-3 m length short rounds with various forms of perimeter control depending on conditions, spilling, and additional shotcrete, bolting walls down to the sill, and additional long bolts (3.6 or $5 \mathrm{~m}$ ). 


\subsection{Roadway construction}

The key to the successful roadway maintenance system in any underground mine is to keep water out of the running surface.

In diamond mines, this rule is even more important due to the weathering susceptibility of the kimberlite. Harsh winter conditions can add another level of difficulty to the roadway maintenance, especially in spring.

In Koala North, all the drawpoints were driven at $+4 \%$ grades to allow water to drain quickly and for ease of equipment recovery. Three roadway designs were tested on the 2355 mining level; $150 \mathrm{~mm}$ granite crush, graded kimberlite, and 'geogrid' beneath $100 \mathrm{~mm}$ crush. The $150 \mathrm{~mm}$ granite crush as required on kimberlite floor provided the optimal acceptable running surface. Kimberlite roadways when frozen from November to June provided excellent pavement surface.

At Diavik, drawpoints are also driven at $+4 \%$ grades. A $75 \mathrm{~mm}$ clean granite crush is used to plate the kimberlite roadways.

\subsection{Mudrush}

Mudrush is an inherent risk for any subsidence mining method. Diamond mines are especially prone to such risk as kimberlite rocks often contain clays which disintegrate upon exposure to water and generate excess fines.

Although the Canadian Arctic does not get excess snowfall or rainfall, it is typically the spring melting (freshet) that generates potentially large quantities of water that can enter the SLR or SLC stopes. So far, only the SLC mine at Koala faced such risk, and the Ekati mine took appropriate measures via strict draw control and teleremote loading to mitigate such risk.

\section{Conclusion}

Both mining operations at the Ekati and Diavik mines proved that not only open pit mining, but also concurrent development and implementation of underground mining in an extremely challenging environment is technically feasible and economically viable.

Both mines had to overcome extreme logistical and technical challenges. This would not be possible without the commitment and dedication of all members of the team and without innovative mining solutions. To date, the SLR method has been completed at Panda (Figure 10) and at Koala North. The SLR method continues to be used as a primary underground mining method at Diavik Diamond Mine.

\section{Acknowledgement}

We gratefully acknowledge the assistance, comments, and input provided by the staff at the Ekati and Diavik diamond mines. We are also thankful for Meilani Zamora Smith and Alice Huynh for help with the compilation of this paper.

\section{References}

Guest AR, 1989, 'The compound ring - an alternative ring configuration to improve mine stability', Proceedings of the Sangorm Symposium on Rock Slope Stability, Sangorm, Marshalltown, pp. 28-33.

Guest AR, 1996, 'The compound ring - post implementation', Proceedings of the SAIMM Colloquium - Massive Mining Methods, The Southern African Institute of Mining and Metallurgy, Johannesburg.

Jakubec J \& Long, L 2004, 'Open benching at Ekati diamond mine - Koala North: case study', in A Karzulovic \& MA Alfaro (eds), Proceedings of MassMin 2004, Instituto de Ingenieros de Chile, Santiago, pp. 433-438.

Jakubec, J, Woodward, R, Boggis, B, Clark, L \& Lewis, P 2017, Underground Mining at Ekati and Diavik Diamond Mines, poster presentation at the 11th International Kimberlite Conference, Gaborone, Botswana.

Paucar, M \& Mthombeni, C 2004, 'Incline cave: a technical alternative method to mine kimberlite deposit at depth', Proceedings of MassMin 2004, Instituto de Ingenieros de Chile, Santiago, pp. 393-396.

Silverton, TR \& Smart, LR 1992, 'The design of compound rings at Finsch mine', in HW Glen (ed.), Proceedings of MassMin 1992, The South African Institute of Mining and Metallurgy, Johannesburg, pp. 125-135. 